\title{
Notes on the vocalizations of Oriental Magpie-robin (Copsychus saularis)
}

Peter Boesman

In the following we briefly analyze and compare voice of the different races of Oriental Magpie-robin (Copsychus saularis). We also try to quantify the extent of any vocal differences using the criteria proposed by Tobias et al. (2010), as a support for taxonomic review. We have made use of sound recordings available on-line from Xeno Canto (XC).

We have only located five recordings from the Philippines, but these seem to indicate an important vocal difference with other races. An overview, illustrated with sonograms:

\section{Philippine group}
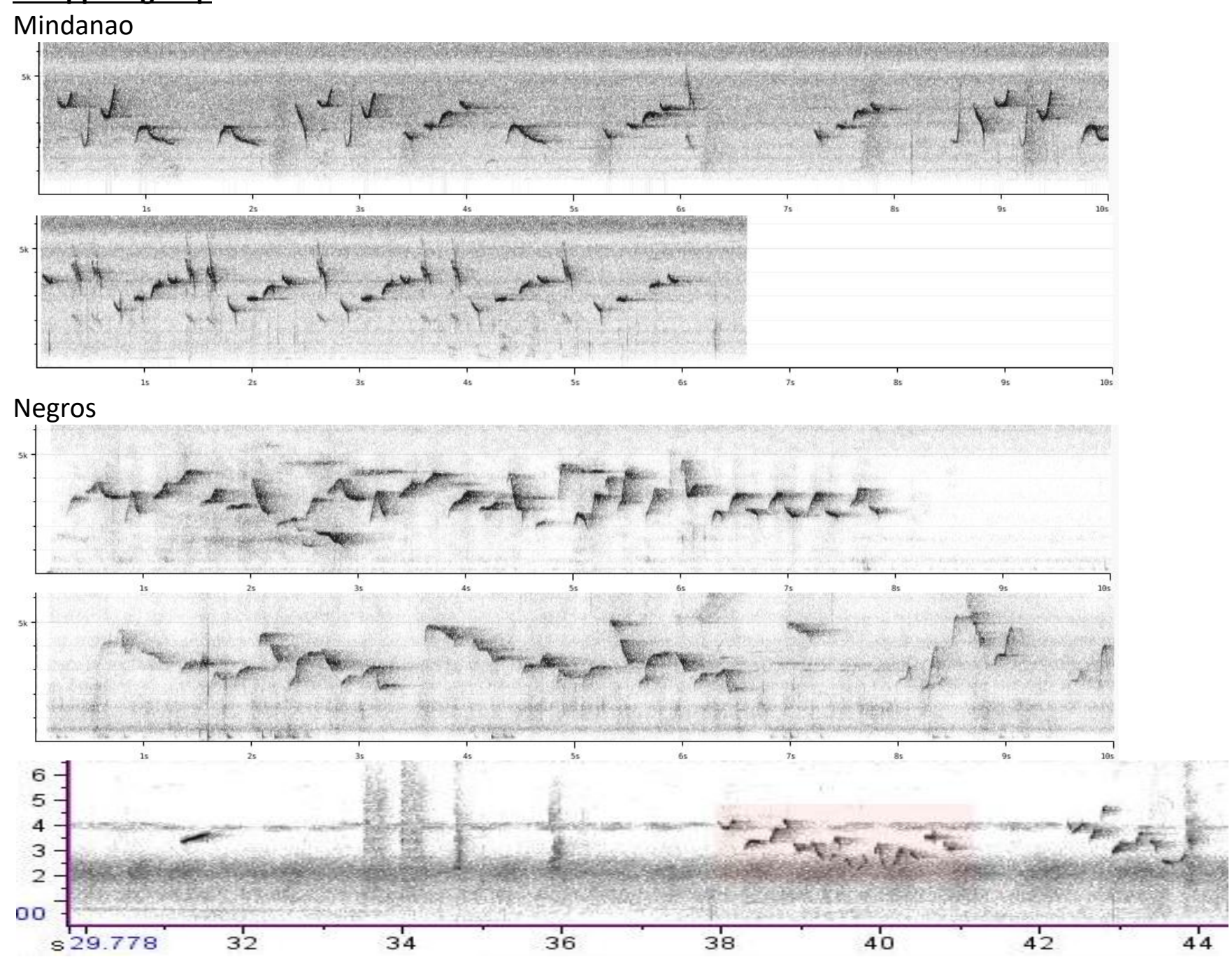


\section{HANDBOOK OF THE \\ BIRDSPFITE WORLD}

ORNITHOLOGICAL NOTES

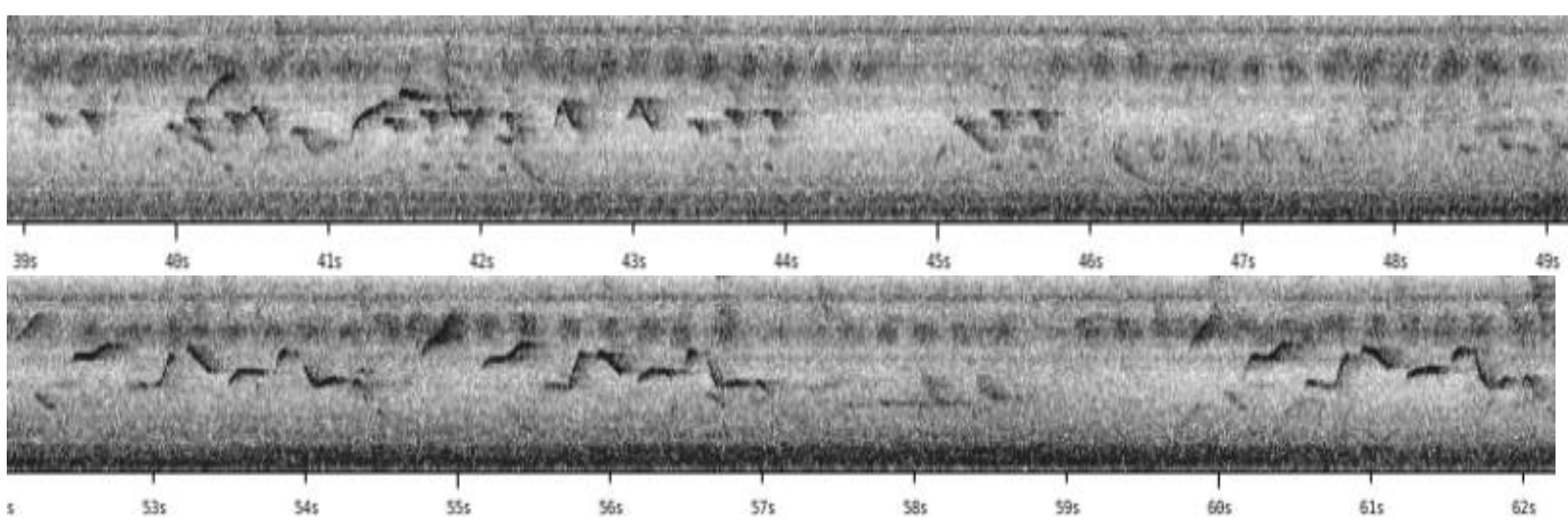

\section{Other races}

adamsi Borneo

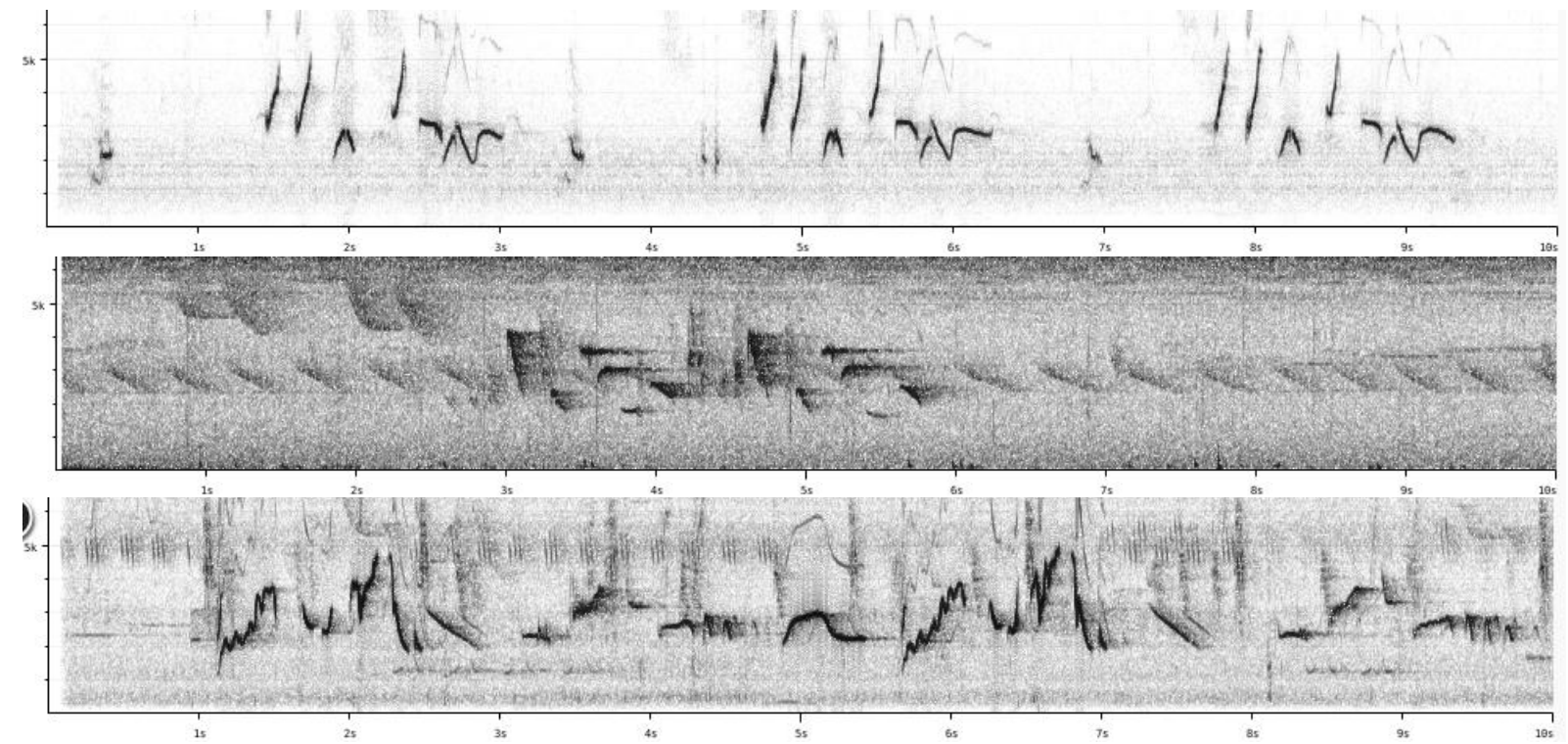

\section{musicus}
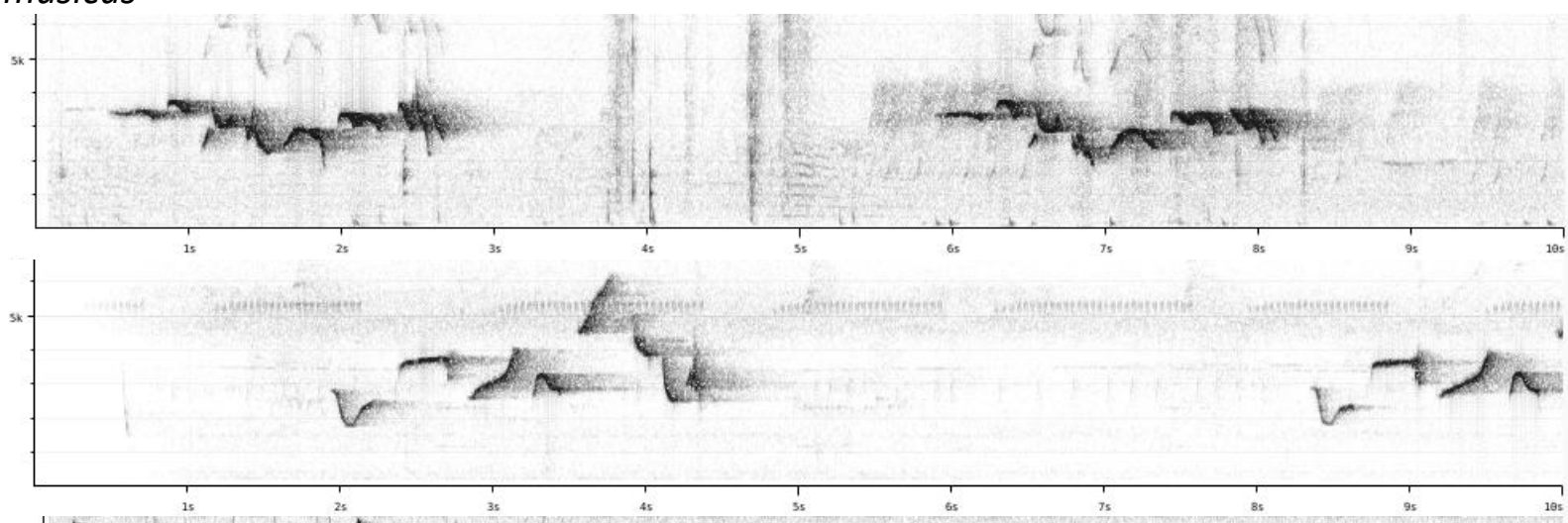

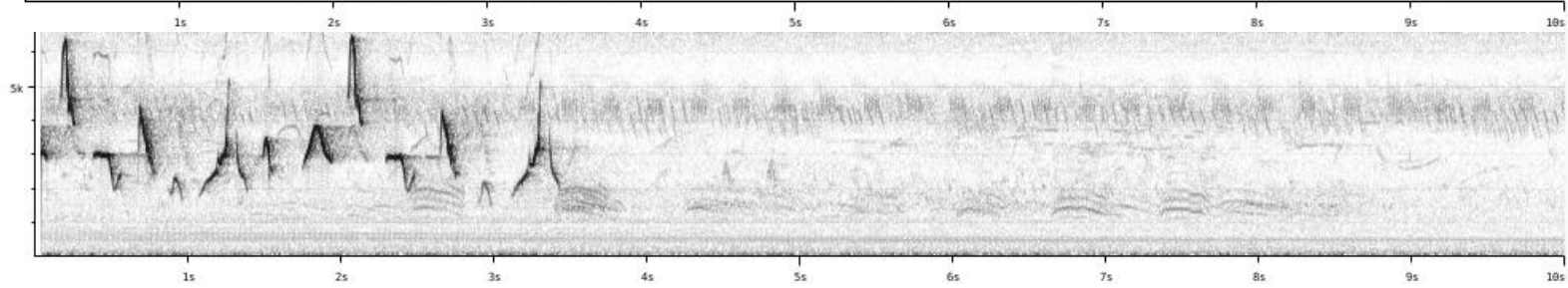


HANDBOOK OF THE

BIRDPPIVE WORLD ORNITHOLOGICAL NOTES

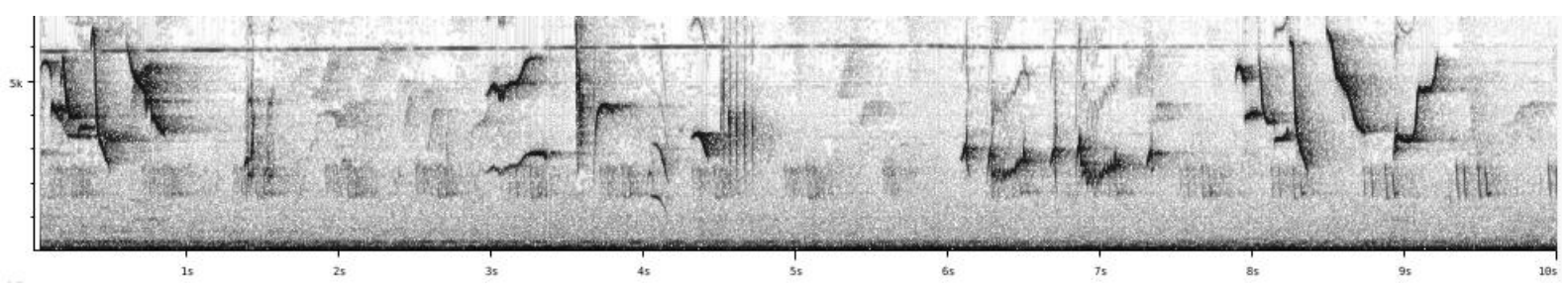

Etc..

For comparison, we also include some examples of closely-related Madagascar Magpie-robin (C. albospecularis):
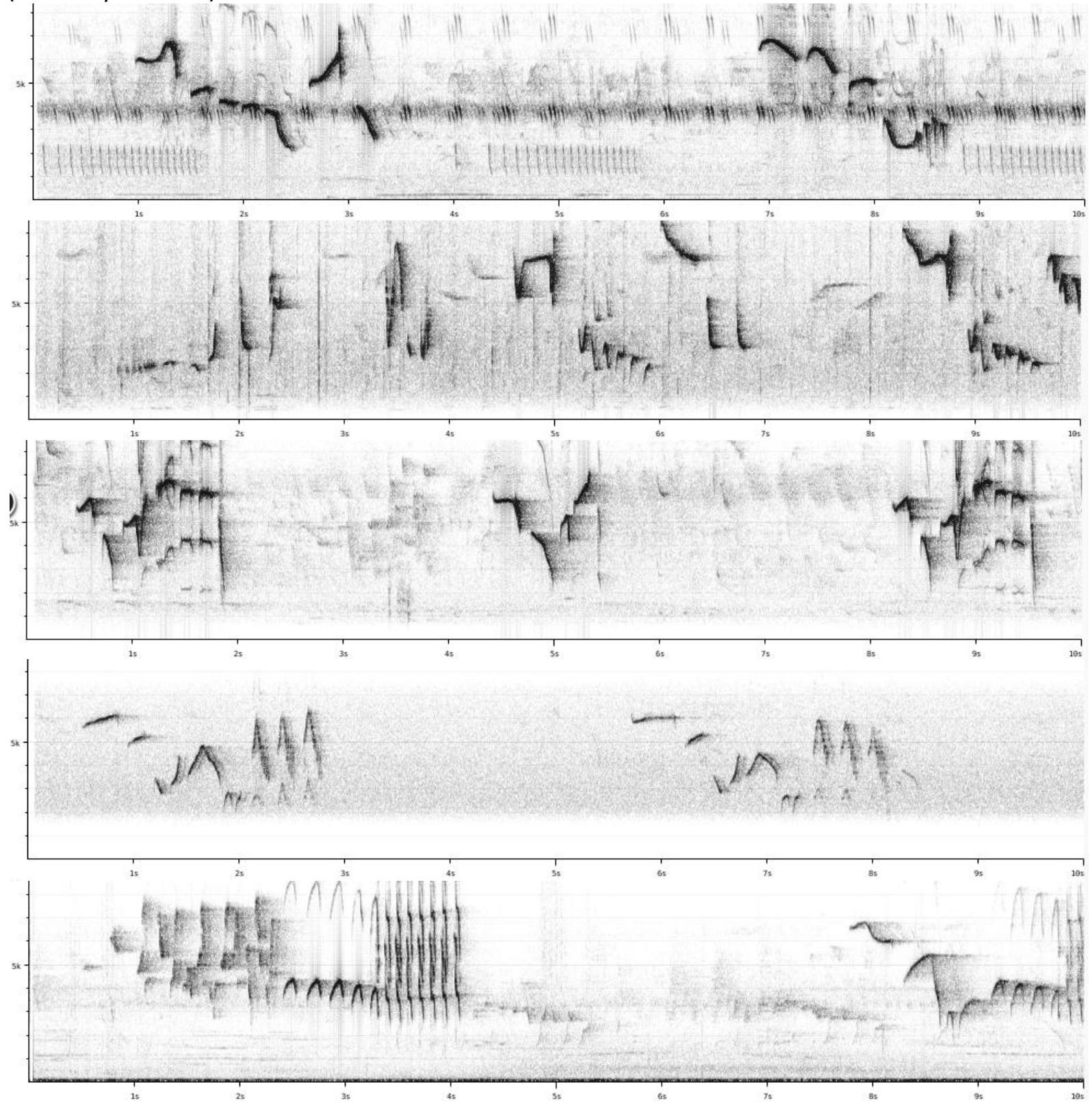

3 

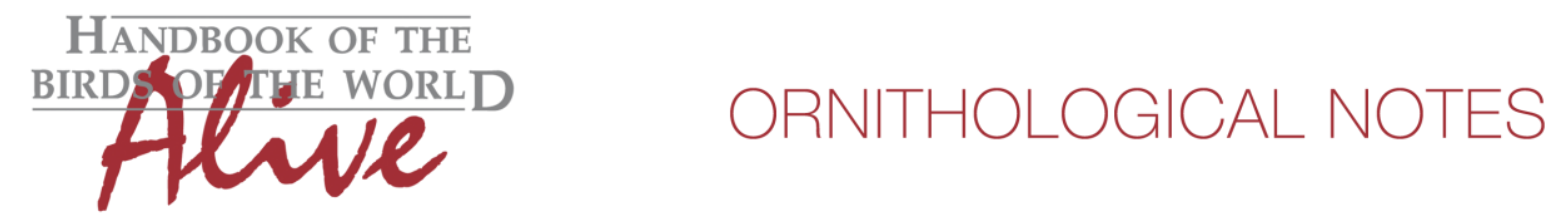

From the above examples, it would seem that, compared to other races of Oriental Magpierobin, pace of Philippine birds is often faster with many short whistled notes, which all stay below $5 \mathrm{kHz}$ and have a rather narrow frequency range (bandwidth mostly between 1 and $1.8 \mathrm{kHz}$ ). Phrases and pauses are irregular in length and composition, hardly ever is there a clear phrase with a distinct longer pause repeated several times (which is often the case in Oriental Magpie-robin). As a result, to the ear it sounds as a sweet, mellow song without much variation.

Oriental Magpie-robin typically has a well-demarcated song strophe followed by a pause of about equal length (not always). In many cases repeated strophes are identical or nearly so. Pace is quite slow, with either long notes or notes covering a wide frequency range (different from Philippines). Some notes reach frequencies to about $6 \mathrm{kHz}$, but definitely not always. Madagascar Magpie-robin shares with Oriental Magpie-robin the rather well-demarcated song strophes separated by pauses of about the same length, and which are often identical or very similarly repeated. Frequency range is however clearly larger, with most song phrases having some notes above $6 \mathrm{kHz}$. To the ear sounding much less mellow.

Vocal differences between the three groups are thus roughly of the same magnitude. An estimated scoring could be given based on Philippine group (vs Oriental Magpie Robin) lacking well separated, repeated song strophes (1), on average shorter notes and faster pace (1), and notes of which max. freq. and freq. range is lower (1-2). Total vocal score expected to be about 2-3.

This note was finalized on 27th August 2016, using sound recordings available on-line at that moment. We would like to thank in particular the many sound recordists who placed their recordings for this species on XC.

\section{References}

Tobias, J.A., Seddon, N., Spottiswoode, C.N., Pilgrim, J.D., Fishpool, L.D.C. \& Collar, N.J. (2010). Quantitative criteria for species delimitation. Ibis 152(4): 724-746.

\section{Recommended citation}

Boesman, P. (2016). Notes on the vocalizations of Oriental Magpie-robin (Copsychus saularis). HBW Alive Ornithological Note 429. In: Handbook of the Birds of the World Alive. Lynx Edicions, Barcelona. (retrieved from http://www.hbw.com/node/1271524 on 8 December 2016). 